ELORE (ISSN 1456-3010), vol. $14-1 / 2007$.

Julkaisija: Suomen Kansantietouden Tutkijain Seura ry.

[http://www.elore.fi/arkisto/1_07/pal1_07.pdf]

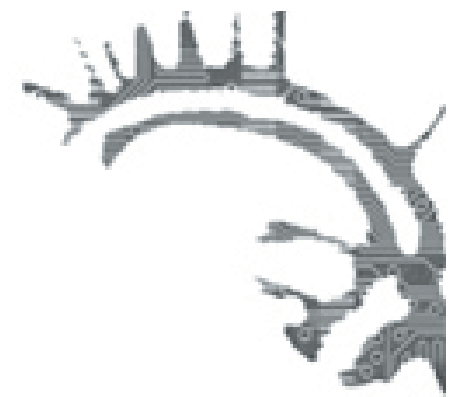

\title{
RECENSION: \\ KÖN, KROPP OCH IDENTITET KONSTRUERAT I MEDIA
}

Mäkelä, Anna \& Puustinen, Liina \& Ruoho, Iiris (red.) 2006: Sukupuolishow. Johdatus feministiseen mediatutkimukseen. Tampere: Gaudeamus. 310 sidor.

\section{$\underline{\text { Ann-Charlotte Palmgren }}$}

I antologin Sukupuolishow, redigerad av Anna Mäkelä, Liina Puustinen och Iiris Ruoho, ingår tretton texter som alla behandlar feministisk medieforskning. Boken kan ses som en introduktion till feministisk medieforskning, men de olika kapitlen ger även den fördjupning som önskas av läsare som redan tidigare är förtrogna med denna typ av forskning. Jag väljer att ge en väldigt kort presentation för att sedan övergå till att närmare se på två kapitel i denna antologi.

I bokens inledning skapas en översikt över feministisk medieforskning, där särskilt kön och genus inom feministisk forskning diskuteras. Inledningen behandlar särskilt feminism inom medieforskning och detta inbegriper att även forskningshistoria och olika klassiker ingående behandlas.

Efter denna introduktion har redaktörerna valt att dela in de övriga artiklarna i två delar. I den första delen är det övergripande temat metodologi. Minna Aslama skriver om kvantitativ och tillämpad medieforskning, medan Leena-Maija Rossi behandlar problematiken som berör kön och reklam. Vidare diskuterar Anu Koivunen heteronormativitet inom filmforskning, Katariina Kyrölä skriver om relationen mellan media och skönhetsideal, Kaarina Nikunen dryftar tematiken kring kroppslighet, pornografi och den feministiska rörelsen medan Susanna Paasonen avslutningsvis diskuterar kön på Internet.

Även om den första delen tar upp flera olika media, är den andra delen särskilt inriktad på olika former av och redskap inom media. Iiris Ruoho ifrågasätter journalismen och dess förhållande till offentlighet, Irma Kaarina Halonen vidareutvecklar diskussionen om hierarki genom att behandla nyhetsinstitutionen och förhållandet till kön inom rumsdiskursen och både Maija Töyry och Jonita Siivonen presenterar problematiken kring damtidningar. Vidare analyserar Hanna Rajalahti feministisk publik- och mottagarforskning och Katja Valaskivi tar upp kön i fakta- samt underhållningstelevisionsprogram. 
Som tidigare nämnts kan boken utmärkt användas som litteratur för läsare som vill bekanta sig med feministisk forskning, detta tack vare att kön diskuteras mycket ingående och lättbegripligt. Boken innehåller en forskningshistorik över synen på kön, kvinnlighet och manlighet med start i början av 1900-talet. Författarna framhäver att dagens feministiska forskning uppmärksammar olikheter mellan män och kvinnor, men även skillnader bland kvinnor och män samt likheter mellan kvinnor och män. Dessutom poängteras att kön kan diskuteras inom kulturella och samhälleliga fenomen och att ålder, etnicitet, kroppslighet, sexualitet och klass kopplas ihop med kön. Även om boken förtiänstfullt ger en introduktion till begrepp och teorier som behandlar patriarkatet, roller, stereotypier, genussystem, konstruktivism och performativitet intresserar de feministiskt medieinriktade fallstudierna mig särskilt. Begreppet show kan vid en första anblick härledas till media. Ofta förknippas televisionsprogram, damtidningar, Internet och pornografi med begreppet show, men bokens författare har inte gjort det för lätt för sig. Begreppet show går som en röd tråd genom hela boken, eftersom kön sammanflätas med teori om performativitet, och problematiseras i och med detta ytterligare.

\section{KROPPSLIGHET OCH IDENTITET, TVÅ FALLSTUDIER}

Även om samtliga texter är intressanta och ger en givande läsning har jag särskilt koncentrerat mig på två kapitel i boken för denna recension. Orsaken till att jag närmare önskat presentera dessa är att jag vill exemplifiera hur boken kan ses som en introduktion till tidigare forskning men även visa hur forskare kan använda denna antologi för att gå vidare och fundera på nya frågor som inte tidigare tagits upp i feministisk medieforskning. Dessa kapitel är "Ruumis, media ja ruumiinkuvat" av Katariina Kyrölä samt Susanna Paasonens avsnitt "Identiteetti internetissä".

Kyrölä skriver att feministisk medieforskning som behandlar kroppslighet oftast koncentrerats på ätstörningar som anorexi och bulimi samt slankhet som ideal i media. Betydligt mindre har forskats i sådant som stängs ute från det västerländska kroppsidealet, till exempel fetma. Det är intressant som Kyrölä skriver att feministisk forskning själv kan anklagas för att betona den smala skönhetsnormen genom att ta den smala och den anorektiska kroppen som utgångspunkt. Även om Kyrölä efterlyser feministisk forskning om kroppen där utgångspunkten inte är ätstörningar, diskuterar författaren tidigare forskning som gäller just detta. Bland annat tar Kyrölä fram forskare som Susie Orbach (1978) och Kim Chernin (1983). Dessa är speciella eftersom de skriver utgående från personliga erfarenheter av ätstörningar. Kyrölä betonar att både Orbach och Chernin endast diskuterat en särskild grupp av kvinnor, nämligen den vita medelklasstillhörande heterosexuella kvinnan. Även om man i stora drag kan se Kyröläs bidrag som en presentation av tidigare feministisk forskning om kroppen, är framför allt hennes jämförelse mellan de olika forskarna och kropparna särskilt intressant. Därtill diskuterar Kyrölä hur kroppen kan innebära makt. Vad kommer då Kyrölä fram till i sin text? Kyrölä konstaterar att medias bild av kroppen inte har 


\section{Ann-Charlotte Palmgren}

ändrats särskilt mycket de senaste åren även om media ibland vill påstå detta. Som ett exempel tar Kyrölä upp sin tidigare forskning som bland annat behandlat den finska Miss XL-tävlingarna där deltagarna endast knappt väger mera än det som benämns normalvikt. Jag ser fram emot att läsa Kyröläs kommande doktorsavhandling som behandlar den feta kroppsligheten och synen på den samt presentationen av den samma inom populära nutidsmedia.

Jag tror att kapitlet skrivet av Susanna Paasonen är särskilt intressant för folklorister och etnologer eftersom det behandlar begreppet identitet. Paasonen inleder med att citera Lisa Nakamura. Nakamura (2002) har hävdat att Internet är ett medium där vem som helst kan vara vem eller vad som helst. Paasonens text är särskilt intressant eftersom hon menar att kön på Internet är relativt outforskat inom Finland. Liksom Kyrölä koncentrerar sig Susanna Paasonen på att diskutera och presentera tidigare internationell (och särskilt nordamerikansk) forskning som behandlat samspelet mellan Internet, kön och identitet. Genom sin presentation av forskare som Sherry Turkle (1995) och Allacquere Rosanne Stone (1995) ger Paasonen en nödvändig introduktion till tidigare forskning som berör identitet och Internet, men Paasonen går även ett steg vidare genom att diskutera performativitet på nätet. Även om Paasonens text i det stora hela är en presentation och diskussion om teorier som berör identitet och Internet, avslutar hon med några ytterst intressanta tankar, vilka jag anser att finländska Internetforskare borde vara medvetna om. Istället för diskussionen om frihet på Internet, borde forskare fundera på vems frihet det är fråga om och hur utgångspunkten ser ut för egen forskning. Paasonen hävdar att teorier om Internetidentiteten ofta bygger på att framhäva frihet och förändring, medan vardagliga sysslor på Internet och Internets samhälleliga betydelse åsidosätts.

\section{ATT INSPIRERA, INTRODUCERA OCH SAMTIDIGT FÖRA DISKUSSIONEN VIDARE}

Finländska medieforskare har gjort ett ytterst välkommet bidrag till både feministisk forskning och medieforskning genom att publicera denna antologi. Vad jag känner till är denna antologi den första finländska publikation som noggrant går in på feministisk medieforskning. Antologin är givande både för studerande och för forskare. Dessutom ger den en mycket välkommen inspiration till andra finländska forskare som forskar om media, kön och identitet. De olika kapitlen och fallstudierna kompletterar varandra ytterst berömligt. Antologin belyser förtjänstfullt tidigare forskning och bakgrund till både media och kön, samt tar upp de kanske viktigaste teorierna inom feministisk forskning.

Detta är en bok som jag gärna återkommer till och jag hoppas att så många som möjligt uppmärksammar denna antologi. Även om jag koncentrerat mig särskilt på två kapitel i boken, önskar jag framföra att samtliga kapitel skulle ha varit förtjänta av större utrymme i denna recension. Samtidigt som jag tror att många traditionsforskare har glädje av boken, ser jag framemot att en liknande antologi någon gång 
i framtiden skulle publiceras där finländska traditionsvetare diskuterar kulturvetenskaplig forskning med inriktning på media.

\section{LITTERATUR}

CHERNIN, KIM 1983: Womansize. The Tyranny of Slenderness. London: The Women's Press.

NAKAMURA, LISA 2002: Cybertypes: Race, Ethnicity, and Identity on the Internet. New York: Routledge.

ORBACH, SUSIE 1978: Fat is a Feminist Issue... The Anti-diet Guide to Permanent Weight Loss. New York: Paddington Press.

STONE, ALLACQUERE ROSANNE 1995: The War of Desire and Technology at the Close of the Mechanical Age. Cambrigde: MIT Press.

TURKLE, SHERRY 1995: Life on Screen: Identity in the Age of the Internet. New York: Simon and Schuster.

FM Ann-Charlotte Palmgren är forskarstuderande i nordisk etnologi vid Åbo Akademi. 